How to Cite

Pooranam, G., \& Nandhini, K. (2019). Customer satisfaction on footwear's in theni district. International Journal of Humanities,

Literature \& Arts, 2(1), 23-27. https://doi.org/10.31295/ijhla.v2n1.57

\title{
Customer Satisfaction on Footwear's in Theni District
}

\author{
G. Pooranam \\ Nadar Saraswathi College of arts \& science, Theni, India \\ K. Nandhini \\ Nadar Saraswathi College of arts \& science, Theni, India \\ Email: nandhini13021995@gmail.com
}

\begin{abstract}
The fashion industry has seen a spurt of growth in the past few years, more so in India. An important part of this fashion boom is the footwear industry. An industry as varied as any other, the footwear industry in India is one of the most competitive and vibrant. This paper seeks to analyses the footwear industry in India, and the buying process that goes into a purchase. With customers becoming increasingly fashion conscious and spendthrift, and the industry becoming more global in its appeal, the consumers" purchase pattern has also seen a shift in terms of various parameters. However, in a diverse Indian market, the entire consumer base can be segmented to use the Bottom of the Pyramid approach. This paper seeks to analyze spending patterns and consumer behavior across the pyramid in the Indian market.
\end{abstract}

Keywords---customer satisfaction, questionnaire survey.

\section{Introduction}

Footwear is the product to protect human feet from effects of all biological damages. The necessity of using footwear was recognized back in the Ice Ages when people realized that they had to keep their feet warm in order to keep themselves healthy. Footwear has undergone a series of changes passing through a journey of inventions. While initially leather and dried grasses were used to wrap around the feet for protection, it evolved into more comfortable wear with leather strapping for a better hold. Eventually it metamorphosed into an accessory and a fashion statement besides providing protection for the feet (Chitra \& Malarvizhi, 2018; Malarvizhi \& Devi, 2018).

Today, footwear is made out a number of materials like leather, PVC, artificial leather, canvas, wood, plastics and cloth. Called by different names, footwear is classified as boots, slippers, flip-flops, shoes, sandals, ballerinas, stilettos and many more depending on the style, make and purpose. Even today, there is a large part of the population who go about bare feet especially in the under-developed countries for the simple reason that they cannot afford them. As the world population increases; so, the living standards of people rise thus increasing the demand for footwear (Mahalakshmi \& Devi, 2018); Pooranam \& Nandhini, 2018).

\section{History}

During the Middle Ages, men and women wore patterns, commonly seen as the predecessor of the modern high-heeled shoe, while the poor and lower classes in Europe, as well as slaves in the New World, were usually barefoot. In the 15 th century, chopines were created in Turkey, and were usually 7-8 inches $(17.7-20.3 \mathrm{~cm})$ high. These shoes became popular in Venice and throughout Europe, as a status symbol revealing wealth and social standing.

During the 16th century, royalty such as Catherine de Medici and Mary I of England began wearing high-heeled shoes to make them look taller or larger than life. By 1580, men also wore them, and a person with authority or wealth might be described as, well-heeled. In modern society, high-heeled shoes are a part of women's fashion and are widespread in certain countries around the world.

ISSN 2632-9441

Received Jan 20, 2019 / Accepted Jun 18, 2019 / Published Jul 05, 2019 


\section{Review of Literature}

Viju Mathew (2008), The leather supply value chain is that it provides an integrated approach to determine and become aware of the problems and constraints from the basic level of rearing animals for the raw skin to purchase and use of finished leather products by the customers.

Ravi Anupindi et al., (2006), Processes are core technologies of all organizations for producing and delivering products that satisfy customer needs "Leather tanning" is a general term for the numerous processing steps involved in converting animal hides or skins into finished leather. Trimming, soaking, fleshing, 25 and unhairing, the first steps of the process, are referred to as the beam house operations. Bating, pickling, tanning, wringing, and splitting are referred to as tan yard processes. Finishing processes include conditioning, staking, dry milling, buffing, spray finishing, and plating.

\section{Statement of the Problem}

The present study "Customer satisfaction on Footwear in Theni district" seeks to address a number of factors and unexplained occurrences present in Footwear. The main objective of this research is to analyze and asses the satisfaction level from the customer. In this research, the researcher focuses on the customer satisfaction level. Footwear are in a position to satisfy this need. Now days the Footwear is customer oriented. The changed environment creating new customers and retaining the existing ones have become difficult tasks for Footwear. To meet the competition, creating satisfaction of customers has become primary objective of Footwear.

\section{Scope of the study}

The study is based on the interview method. This study covers" A Study on customer satisfaction on Footwear in Theni district".

\section{Objectives of the study}

The following are the objectives for this study.

a) To analyze the customer satisfaction on Footwear in Theni District.

b) To study the perception of different age groups towards Footwear customer avenues.

c) To study the customer satisfaction level of Footwear by assessing and interviewing customers from different establishments.

d) To provide a set of empirical data that can link relationships for customer level of satisfaction.

\section{Data Collection}

Both primary and secondary data used in in the present study.

Primary data collected through personal interview in the form of questionnaire form 80 respondents.

Secondary data collected from various journals, books, magazines.

\section{Tools for Analysis}

The collected data has been analyzed by using following statistical tools:

a) Percentage Analysis

b) Garrett Ranking

c) Likert Scaling

\section{Limitation of the study}

a) The study is limited to respondents from Theni district.

b) This project concentrates on the services given to customer in general. Therefore, it is difficult to study the view of the customers towards one particular service.

c) It was difficult to study what happens to customer satisfaction when we initially perceive a service provider as being less than general than overtime, that service provide warms up unexpectedly. 
Analysis of Data

1) Socio Economic status of the respondents

Table 1

Socio Economic status of the respondents

\begin{tabular}{|c|c|c|c|}
\hline \multicolumn{4}{|c|}{ Gender } \\
\hline Variables & Categories & $\begin{array}{c}\text { No of } \\
\text { respondents }\end{array}$ & Percentage \\
\hline \multirow{2}{*}{ Sex } & Male & 27 & 34 \\
\hline & Female & 53 & 66 \\
\hline \multicolumn{4}{|c|}{ Age of the respondents } \\
\hline & 18-30years & 49 & 61 \\
\hline \multirow{3}{*}{ Age } & $30-40$ years & 19 & 24 \\
\hline & $40-50$ years & 11 & 14 \\
\hline & above 50 years & 1 & 1 \\
\hline \multicolumn{4}{|c|}{ Educational Qualification of the respondents } \\
\hline & Up to school level & 3 & 14 \\
\hline Educational & Diploma/Technical & 11 & 24 \\
\hline \multirow{2}{*}{ Qualification } & Under graduate & 13 & 21 \\
\hline & Professional & 33 & 41 \\
\hline \multicolumn{4}{|c|}{ Occupation of the respondents } \\
\hline \multirow{4}{*}{ Occupation } & Business & 17 & 21 \\
\hline & Government employee & 25 & 31 \\
\hline & Private employee & 26 & 33 \\
\hline & House wife & 12 & 15 \\
\hline \multicolumn{4}{|c|}{ Monthly income of the respondents } \\
\hline \multirow{4}{*}{ Monthly income } & Below Rs.7000 & 10 & 12 \\
\hline & Rs7001-Rs15000 & 15 & 19 \\
\hline & Rs15001-Rs20000 & 27 & 34 \\
\hline & Above Rs 25000 & 28 & 35 \\
\hline
\end{tabular}

From the above table 1 interpret that majority of the respondents (66\%) is under Female category, (61\%) respondents are under age group of 18-30years; Under education qualification of the respondents, most of the respondents are (24\%) having the qualification of Diploma/Technical, (33\%) of the respondents are doing the private employee, $(35 \%)$ of the respondents having monthly Income above 25000.

\section{Satisfaction Factors Analysis}

Likert Scaling Techniques

Rensis Linker's was instruments in developing summated rating scale based on item analysis. Likert scale is by for the most popular of all measurement scales. It is meant for measuring original attributes like attitudes. It is designed to measure the intensity with which an attitude is expressed. This scale consists of a number of statements which express either a favorable or unfavorable attribute towards the object of the study. The respondents are asked to respond to each statement in terms of 5 degrees of satisfaction.

As 5 point Likert's scaling technique is used to find out the most satisfied factor, points were given as below.

Highly Satisfied - 5 Points

Satisfied -4 Points

Moderate -3 Points

Dissatisfied - 2 Points

Highly dissatisfied - 1 Point 


\section{Satisfaction Level of present practices in commercial banks}

The following table 2.1indicates that ranks of level of satisfaction of the respondents. The process of account opening main factor for satisfaction; ATM facility is the second factor for satisfaction; Charges is the third reason for satisfaction in commercial banks; Location\& Mobile banking is fourth reason for satisfaction; Process of loan are the sixth reason for satisfaction; Online banking is the seventh reason for satisfaction in commercial banks.

Table 2

Customer satisfaction on foot wears

\begin{tabular}{|c|c|c|c|c|c|c|c|c|}
\hline S.No & Factors & $\begin{array}{c}\text { Highly } \\
\text { satisfied (5) }\end{array}$ & $\begin{array}{l}\text { Satisfied } \\
\text { (4) }\end{array}$ & $\begin{array}{l}\text { Moderate } \\
\text { (3) }\end{array}$ & $\begin{array}{l}\text { Dissatisfied } \\
\text { (2) }\end{array}$ & $\begin{array}{c}\text { Highly } \\
\text { dissatisfied (1) }\end{array}$ & Total & Rank \\
\hline \multirow[t]{2}{*}{1} & \multirow{2}{*}{$\begin{array}{l}\text { Variety of } \\
\text { Footwear }\end{array}$} & 61 & 16 & 2 & 1 & 0 & \multirow[t]{2}{*}{377} & \multirow[t]{2}{*}{ I } \\
\hline & & 305 & 64 & 6 & 2 & 0 & & \\
\hline \multirow[t]{2}{*}{2} & \multirow[t]{2}{*}{ Suitability } & 19 & 36 & 21 & 2 & 2 & \multirow[t]{2}{*}{308} & \multirow[t]{2}{*}{ VI } \\
\hline & & 95 & 144 & 63 & 4 & 2 & & \\
\hline \multirow[t]{2}{*}{3} & \multirow[t]{2}{*}{ Location } & 32 & 19 & 24 & 5 & 0 & \multirow[t]{2}{*}{318} & \multirow[t]{2}{*}{ IV } \\
\hline & & 160 & 76 & 72 & 10 & 0 & & \\
\hline \multirow[t]{2}{*}{4} & \multirow{2}{*}{$\begin{array}{l}\text { Process } \\
\text { purchasing }\end{array}$} & 31 & 24 & 10 & 12 & 3 & \multirow[t]{2}{*}{308} & \multirow[t]{2}{*}{ VI } \\
\hline & & 155 & 96 & 30 & 24 & 3 & & \\
\hline \multirow[t]{2}{*}{5} & \multirow[t]{2}{*}{ Charges } & 30 & 30 & 11 & 5 & 4 & \multirow[t]{2}{*}{321} & \multirow[t]{2}{*}{ III } \\
\hline & & 150 & 120 & 33 & 10 & 8 & & \\
\hline \multirow[t]{2}{*}{6} & \multirow{2}{*}{$\begin{array}{l}\text { ATM } \\
\text { facility }\end{array}$} & 32 & 28 & 16 & 3 & 1 & \multirow[b]{2}{*}{327} & \multirow[b]{2}{*}{ II } \\
\hline & & 160 & 112 & 48 & 6 & 1 & & \\
\hline \multirow[t]{2}{*}{7} & Mobile & 34 & 23 & 13 & 7 & 3 & \multirow[t]{2}{*}{318} & \multirow[t]{2}{*}{ IV } \\
\hline & payment & 170 & 92 & 39 & 14 & 3 & & \\
\hline \multirow[t]{2}{*}{8} & Online & 26 & 24 & 18 & 10 & 2 & \multirow[t]{2}{*}{302} & \multirow[t]{2}{*}{ VII } \\
\hline & purchasing & 130 & 96 & 54 & 20 & 2 & & \\
\hline
\end{tabular}

(Source: Computed data)

Ranking method it is used to analyze the main functions of commercial banks.

\section{Findings and Suggestions}

\section{Findings}

By applying various statistical measures for analyzing the primary data collected from the 80 respondents regarding A Study on Customer Satisfaction on Commercial Banks in Theni District, the researcher's findings were:

a) Out of 80 respondents $66 \%$ of the respondents are female.

b) Out of 80 respondents $61 \%$ belongs to the age group between 18-30years.

c) Majority of the respondents $55 \%$ are unmarried.

d) $41 \%$ of the customers are professional course.

e) Out of 80 respondents $35 \%$ of the respondents having earnings of above 25000 . Out of 80 respondents $33 \%$ of the respondents are in private employee.

Suggestion

a) The company can introduce more variety of products.

b) The company may try to increase the advertisement in several Medias.

c) The company may try to concentrate on health related footwear.

d) The company can increase the dealers.

e) The company can concentrate on youth related footwear. 


\section{Conclusion}

Thus, the study concludes that the footwear industry in India is expanding at an incredible rate. Local brands like Bata, Paragon, Liberty, Khadims, and Relaxo are popular among lower income and middle-income groups, while the topof-the-pyramid segment clamors after the international brands like Woodland, Nike, Reebok, Adidas, FILA, Catwalk, Inc5 and Puma. The poorest consumers also desire self-esteem and social recognition and buy items that not only fulfill their needs but also look nice and make them feel better. They also satisfy this need by using the hand-me-downs of the top-of-the-pyramid consumers.

\section{References}

Chitra, S., \& Malarvizhi, M. (2018). A study on Consumer Reaction on Passenger Car Tyre Selection in Theni. International Research Journal of Management, IT and Social Sciences, 5(2), 64-68.

Clottey, T. A., Collier, D. A., \& Stodnick, M. (2008). Drivers of customer loyalty in retail store environment. Journal of Service Science, 1(1).

Haghighi, M., Dorosti, A., Rahnama, A., \& Hoseinpour, A. (2012). Evaluation of factors affecting customer loyalty in the restaurant industry. African Journal of Business Management, 6(14), 5039-5046.

Hart, S. L. (2005). Capitalism at the crossroads: The unlimited business opportunities in solving the world's most difficult problems. Pearson Education.

Mahalakshmi, G., \& Devi, M. A. (2018). A Study on Customer Satisfaction towards in Health Drinks in Theni District. International Research Journal of Management, IT and Social Sciences, 5(2), 69-74.

Malarvizhi, J., \& Devi, T. C. (2018). A Study on Customer Satisfaction towards Patanjali Products in Theni District. International Research Journal of Management, IT and Social Sciences, 5(2), 75-79.

Pooranam, G., \& Nandhini, K. (2018). A Study on Customer Satisfaction on Commercial Banks in Theni District. International Research Journal of Management, IT and Social Sciences, 5(2), 41-46.

Prahalad, C. K. (2009). The fortune at the bottom of the pyramid, revised and updated 5th anniversary edition: Eradicating poverty through profits. FT Press. 